\title{
Helicobacter spp. and gastric lesions association in minipigs
}

\section{Renato Luiz Silveira ${ }^{*}$ (i) Ana Claudia de Menezes Cruz $^{2}$ (i) Hassan Jerdy Leandro ${ }^{3}$ (i) Mariah Bianchi Reis Gusmão Petronilha ${ }^{3}$ Rachel Bittencourt Ribeiro Rodrigues $^{3}(\mathbb{D}$ Maria Aparecida da Silva ${ }^{4}$ Raphael Mansur Medina ${ }^{5}$ (D) Fabiana Batalha Knackfuss ${ }^{6}$ (1) Eulógio Carlos Queiroz de Carvalho ${ }^{3}$ (1)}

\footnotetext{
'Departamentos de Morfologia, Patologia e Clínica Veterinária, Universidade Federal Fluminense (UFF), 24210-130, Niterói, RJ, Brasil. E-mail: renatosilveira@id.uff.br. "Corresponding author.

${ }^{2}$ Núcleo de Animais de Laboratório (NAL), Universidade Federal Fluminense (UFF), Niterói, RJ, Brasil.

${ }^{3}$ Programa de Pós-graduação em Ciência Animal (PGA), Universidade Estadual do Norte Fluminense Darcy Ribeiro (UENF), Campos dos Goytacazes, RJ, Brasil.

${ }^{4}$ Departamento de Biologia, Centro de Ciências Exatas, Naturais e da Saúde (CCENS), Universidade Federal do Espírito Santo (UFES), Alegre, ES, Brasil.

${ }^{5}$ Faculdade de Veterinária, Universidade Iguaçú (UNIG), Itaperuna, RJ, Brasil.

${ }^{6}$ Escola de Ciências da Saúde, Faculdade de Veterinária, Universidade do Grande Rio (UNIGRANRIO), Duque de Caxias, RJ, Brasil.
}

ABSTRACT: Due to their similarity to humans, studies regarding gastric ulcers in pigs have become of great interest. It is known that Helicobacter spp. is related to the occurrence of these ulcers, as they possess a high prevalence in pigs. This study aimed to associate gastric lesions findings naturally occurring in minipigs related to or not related to the presence of Helicobacter spp., through the ultra-rapid urease test and immunohistochemical analysis, reaffirming the disease in swine as a natural biomedical model for human cases. For this, samples of formalin-fixed paraffin-embedded gastric tissues from 40 minipigs were obtained at the Laboratório de Morfologia e Patologia Animal (LMPA) in the Universidade Estadual do Norte Fluminense (UENF). Regarding the ultra-rapid urease test, no animal was positive in all regions. However, 18 were positive in at least one: six (15\%) were positive in the aglandular region, eight (20\%) in the antrum region, 13 (32.5\%) in the region of the cardiac gland, and one (2.5\%) in the region of the fundic gland. Regarding immunohistochemical analysis, only one animal was positive in all regions, and 32 animals were positive in at least one: four (10\%) were positive in the aglandular region, 10 (25\%) in the antrum region, $23(57.5 \%)$ in the region of the cardiac gland, and three (7.5\%) in the region of the fundic gland. The gastric lesion findings showed a close relationship with Helicobacter spp., enriching the laboratory animal pathologies list. The immunostaining of the bacteria not associated with gastric lesions in certain regions demonstrated the saprophytic and opportunisitic nature of Helicobacter.

Keywords: gastric ulcer, Helicobacter, immunohistochemistry, swine, ultrarapid urease test.

\section{Associação entre Helicobacter spp. e lesões gástricas em minipigs}

RESUMO: Por sua semelhança com a da espécie humana, a úlcera gástrica nos suínos tem despertado muito interesse. Sabe-se que o Helicobacter spp. está relacionado à ocorrência dessas úlceras, apresentando alta prevalência. Este estudo teve como objetivo associar as lesões gástricas, de ocorrência natural em miniporcos, à presença, ou não, de Helicobacter spp., por meio do teste ultra-rápido da urease e da análise imunohistoquímica, reafirmando a enfermidade em suínos como modelo biomédico natural para os casos em humanos. Para este fim, foram utilizados histossetes de tecido gástrico de 40 minipigs obtidos no Laboratório de Morfologia e Patologia Animal (LMPA) da Universidade Estadual do Norte Fluminense (UENF). Em relação ao teste ultra-rápido da urease, nenhum animal foi positivo em todas as regiões, entretanto, 18 foram positivos em pelo menos uma: seis foram positivos na região aglandular, oito na região do antro, 13 na região das glândulas cárdicas e um na região das glândulas fúndicas. Em relação à análise imuno-histoquímica, somente um animal foi positivo em todas as regiões e 32 animais foram positivos em pelo menos uma: quatro foram positivos na região aglandular, 10 na região do antro, 23 na região das glândulas cárdicas e três na região das glândulas fúndicas. As lesões gástricas demonstraram estreita relação com o Helicobacter spp. em miniporcos, enriquecendo a lista de patologias de animais de laboratório. A imunomarcação da bactéria não associada à lesão, em certas regiões gástricas, demonstra seu caráter saprofitico e oportunista.

Palavras-chave: Helicobacter, imuno-histoquímica, suíno, teste ultra-rápido da uréase, úlcera gástrica.

\section{INTRODUCTION}

Due to their similarity to humans, studies regarding gastric ulcers in pigs have become of great interest (DE BRUYNE et al., 2012), especially the infectious causes (THOMSON \& FRIENDSHIP, 2019). It is known that Helicobacter spp. is related to the occurrence of these ulcers, as they possess 
a high prevalence in pigs, which in turn reduced daily weight gain (DE BRUYNE et al., 2012); and subsequently, led to economic losses (KUMAR et al., 2010). Many studies show a high prevalence of gastric ulcers, which deserve further investigation on their risk factors (GOTTARDO et al., 2017; DE WITTE et al., 2019).

The bacteria Helicobacter suis has been associated with gastric lesions in pigs and humans (DE BRUYNE et al., 2016; NAKAGAWA et al., 2018; RIMBARA et al., 2020), This leads to a major concern, since according to the data presented in the literature, people in close contact with pigs are exposed to higher risks of infection, suggesting that this animal is a zoonotic agent (JOOSTEN et al., 2013; LOUGHLIN et al., 2019). Helicobacter suis is one of the most prevalent non-H. pylori sp. in humans (LIANG et al., 2013), and Helicobacter pylori is the most important gastric Helicobacter in human health (HRISTOVA et al., 2017).

There are several similarities regarding the anatomy, physiology, and pathophysiology between pigs and humans, but, due to several limitations such as animal handling, breeding space, and food volume, laboratory dimensions colonies have been developed. These colonies are used in many areas of medical and biological research (MARIANO, 2003) and have replaced other mammalian species, such as animal models (SWINDLE \& SMITH, 2016).

This study aimed to associate gastric lesions findings naturally occurring in minipigs related to or not related to the presence of Helicobacter spp. through the ultra-rapid urease test and immunohistochemical (IHC) analysis, reaffirming the disease in swine as a natural biomedical model for human cases.

\section{MATERIALS AND METHODS}

The samples were obtained at the Laboratório de Morfologia e Patologia Animal (LMPA). Samples of the aglandular (pars Oesophagea) and glandular (cardia, fundus and pylorus) anatomical regions were collected for ultra-rapid urease test (fresh samples) and immunohistochemical (IHC) evaluations (samples fixed in buffered neutral formalin).

For this study, samples of formalin-fixed paraffin-embedded gastric tissues from 40 minipigs were used (SILVEIRA et al., 2015). The piglets had an average weight of $39.0 \mathrm{Kg}$ and an average age of 17 months, were kept in the colony of the UENF Veterinary Hospital under constant temperature and humidity conditions, and fed twice a day.
Aglandular region integrity has been observed in macroscopic evaluation. The ulcerative lesions were classified using the scoring method proposed by SILVEIRA et al. (2014), from zero to five: assigning the score 0 to a normal appearance (smooth, glossy and whitish); score 1 to those with that were partially rough looking, with any yellow pigmentation; score 2 to the ones with fully rough and thickened areas of yellow pigmentation; score 3 to totally rough and thickened aglandular areas associated with yellow pigmentation of the entire surface; score 4 to the ones with totally rough and thickened areas, with the entire surface covered in yellow pigmentation, and eroded areas; and score 5 to those with a rough and thickened appearance, yellow pigmentation on its entire surface, and ulceration areas.

For the ultra-rapid urease test results, we used the criterion of negative (unchanged color) and positive (changed color) during the first five minutes (Figure 1). With this time, about $80 \%$ was already confirmed, but following the laboratory's recommendation, we expected to wait up to two hours for the final result.

To perform the immunohistochemical technique (Figure 1), $4 \mu \mathrm{m}$ sections were made in those regions. These, in turn, were deparaffinized in xylene baths, and rehydrated in alcohol and deionized water baths. Then, the process for antigen retrieval was made using citrate buffer in a $96{ }^{\circ} \mathrm{C}$ water bath, followed by endogenous peroxidase blocking when the specimens were treated with an alcoholic solution (methanol) of $10 \%$ hydrogen peroxide. After carefully drying the slides, sections were circled with a Dako pen ${ }^{\circledR}$ (Dako, CA, USA), and incubated with $1 \%$ bovine serum albumin fatty acid-free solution and $1 \%$ skimmed milk powder diluted in Tris-NaCl for blocking nonspecific proteins. After discarding the blocking solution, the sections were incubated overnight in a humid chamber in a 1:200 dilution of rabbit polyclonal anti-Helicobacter pylori Rabbit antibody, Dako, B047. The next day, the slides were washed with brine, treated with HRPLSAB + kit (Dako, CA, USA), and developed with DAB chromogen kit (Dako, CA, USA). Finally, the specimens were counterstained with Harris hematoxylin, dehydrated in alcohol baths, and mounted in synthetic resin. To analyze the slides, we used light optical microscopy. The antibody used (Helicobacter spp.) is also used for diagnosis in other species at the UENF university hospital. Samples previously tested were used for the positive and negative controls (SILVEIRA et al., 2014). 


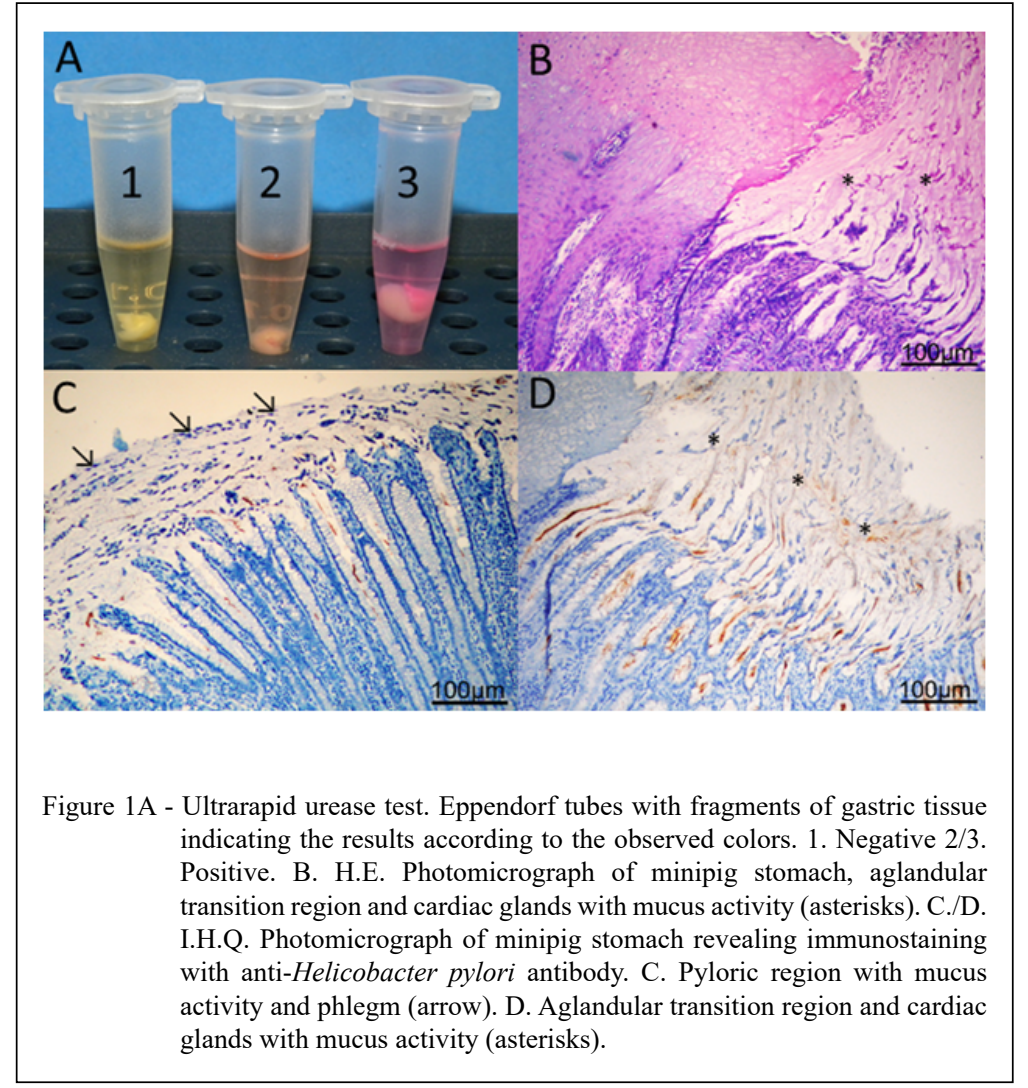

To evaluate the frequency of positive animals in relation to gastric lesions, immunohistochemical findings, and ultra-rapid urease tests, the chi-square or Fisher's exact test was performed, considering a $5 \%$ probability of error. For all analyzes, the program SPSS ${ }^{\circledR} \mathrm{IBM}-\mathrm{v} 18.0$ was used.

\section{RESULTS AND DISCUSSION}

Although, there are differences between naturally occurring gastric ulcers between pigs and humans, the pig represents an interesting animal model to study the repair of gastric ulcers (KOGA et al., 2002; PADRA et al., 2018; BANG et al., 2019; MAEDA et al., 2019), and the pathogenic mechanisms involved in their formation, mainly with Helicobacter pylori (POUTAHIDIS et al., 2001). Pigs have systemic similarities with humans and a suitable profile for biomedical research (GIANOTTI et al., 2010).

Regarding the ultra-rapid urease test, in the four regions, 22 animals (55\%) were negative, and 18 animals $(45 \%)$ were positive in at least one of them. However, none of them were positive in all regions. In contrast to these results, other authors reported higher percentages. MCNICHOLL et al. (2017) found 74\% positive results, FRIEDRICH et al. (2019) reported $90 \%$, and OKUBO et al. (2017) reported $94.7 \%$. The ultra-rapid urease test is qualitative, and the results are variable according to laboratory and examination time. Moreover, slight color changes, even if positive, cannot be distinguished from what is considered normal (MCINTOSH et al., 2010). This difference in results showed a limitation of the technique. Despite presenting a low cost and fast results (VARGAS et al., 2019), it should only be used as an indicative test. According to the authors, further research should be done, comparing several commercially available tests. Concerning the antrum region, eight $(20 \%)$ were positive, and $32(80 \%)$ were negative. In the aglandular region, six (15\%) were positive, and 34 $(85 \%)$ were negative. For the region of the cardiac gland, $13(32.5 \%)$ were positive, and 27 (67.5\%) were negative. Regarding the region of the fundic gland, one animal was positive $(2.5 \%)$, and 39 (97.5\%) were negative. According to these results, there was no statistically significant association between the bacteria and the lesions (Table 1). In an endoscopic

Ciência Rural, v.51, n.3, 2021. 
Table 1 - Presence of Helicobacter spp. in the gastric mucosa of minipigs with different scores of injury, according to the Urease Test. Reference: Silveira et al. (2015).

\begin{tabular}{|c|c|c|c|c|c|c|c|c|}
\hline & $\begin{array}{l}\text { Presence of } \\
\text { Helicobacter } \\
\text { spp }\end{array}$ & Score 0 & Score 1 & Score 2 & Score 3 & & & Total \\
\hline \multirow{4}{*}{$\begin{array}{l}\text { Aglandular } \\
\text { portion }^{1}\end{array}$} & Positive & 0 & 2 & 2 & 2 & & & 6 \\
\hline & Negative & 11 & 13 & 7 & 3 & & & 34 \\
\hline & Total & 11 & 15 & 9 & 5 & & & 40 \\
\hline & & Normal & Mucus activity & Erosion & Hyperemia & $\begin{array}{c}\text { Neutrophilic } \\
\text { Exudate }\end{array}$ & Phlegm & \\
\hline \multirow{4}{*}{$\begin{array}{l}\text { Glandular } \\
\text { portion } \\
(\text { Anthrum) })^{2}\end{array}$} & Postitive & 5 & 2 & 0 & 0 & 0 & 1 & 8 \\
\hline & Negative & 21 & 5 & 0 & 0 & 0 & 6 & 32 \\
\hline & Total & 26 & 7 & 0 & 0 & 0 & 7 & 40 \\
\hline & & Normal & Mucus activity & Erosion & Hyperemia & $\begin{array}{c}\text { Neutrophilic } \\
\text { Exudate }\end{array}$ & Phlegm & \\
\hline \multirow{4}{*}{$\begin{array}{l}\text { Glandular } \\
\text { portion } \\
\text { (Fundus) }^{3}\end{array}$} & Positive & 2 & 5 & 4 & 0 & 1 & 1 & 13 \\
\hline & Negative & 7 & 3 & 2 & 1 & 4 & 10 & 27 \\
\hline & Total & 9 & 8 & 6 & 1 & 5 & 11 & 40 \\
\hline & & Normal & Mucus activity & Erosion & Hyperemia & $\begin{array}{c}\text { Neutrophilic } \\
\text { Exudate }\end{array}$ & Phlegm & \\
\hline \multirow{3}{*}{$\begin{array}{l}\text { Glandular } \\
\text { portion } \\
(\text { Body) }\end{array}$} & Positive & 1 & 0 & 0 & 0 & 0 & 0 & 1 \\
\hline & Negative & 28 & 2 & 4 & 1 & 1 & 3 & 39 \\
\hline & Total & 29 & 2 & 4 & 1 & 1 & 3 & 40 \\
\hline
\end{tabular}

${ }^{1}\left(\chi^{2}=4.79 ; \mathrm{P}=019\right),{ }^{3}\left(\chi^{2}=10.49 ; \mathrm{P}=0.06\right),{ }^{4}\left(\chi^{2}=0.39 ; \mathrm{P}=0.99\right)$

study with piglets, SILVEIRA et al. (2014) reported $65 \%$ of the animals positive, but also did not observe a statistical association between bacteria and injuries. Regarding the immunohistochemical analysis, eight animals (20\%) were negative in all regions, while $32(80 \%)$ were positive in at least one, but only one animal (2.5\%) was positive in all of them. SZEREDI et al. (2005) reported $85.4 \%$ positivity in all regions in their studies, while SILVEIRA et al. (2014) reported 50\% negative in all regions, and $50 \%$ positive in at least one of the regions. Regarding the antrum region, $10(25 \%)$ were positive, and 30 (75\%) were negative. In the aglandular region, four (10\%) were positive, and $36(90 \%)$ were negative. Concerning the region of the cardiac gland, 23 (57.5\%) were positive, and 17 (42.5\%) were negative. For the region of the fundic gland, three $(7.5 \%)$ were positive, and $37(92.5 \%)$ were negative (Table 2). SILVEIRA et al. (2014), in an endoscopic study with piglets, reported $10(50 \%)$ positives in the antrum region, two $(10 \%)$ positives in the aglandular region, three $(15 \%)$ positives in the region of the cardiac gland, and two $(10 \%)$ positives in the region of the fundic gland. According to these results, the impact of bacterial infection on the stomach and on the health of herds associated with the potential to cause disease in humans, justifies the interest of further studies on the subject (TAMIASSO et al., 2017).

In the study presented herein, we observed statistically significant differences regarding the presence of bacteria in the aglandular region and in the region of the cardiac glands (Table 2). In the others, the bacterium was immunostained but not associated with the affected region. This led to the assumption that these agents may dwell saprophytically and opportunistically in the gastric mucosa. In a study with slaughter animals, RODRIGUEZ et al. (2008) also reported an association of the bacteria with the aglandular region. DE WITTE et al. (2017), found a similar result, but unlike this study, the statistical association occurred in the region of the pyloric glands. Furthermore, regarding IHC, SZEREDI et al. (2005) observed that a higher infection rate was found in the cardiac region, followed by the pyloric and fundus regions.

HAESEBROUCK et al. (2009) reported that Helicobacter suis is associated with gastritis and ulcers, and KUMAR et al. (2010) drew attention to 
Table 2 - Presence of Helicobacter spp. in the gastric mucosa of minipigs with different lesion scores, according to the immunohistochemical. Reference: Silveira et al. (2015).

\begin{tabular}{|c|c|c|c|c|c|c|c|c|}
\hline & $\begin{array}{l}\text { Presença de } \\
\text { Helicobacter } \\
\text { spp. }\end{array}$ & Score 0 & Score 1 & Score 2 & Score 3 & & & Total \\
\hline \multirow{4}{*}{$\begin{array}{l}\text { Aglandular } \\
\text { Portion }^{1}\end{array}$} & Positive & 0 & 0 & 2 & 2 & & & 4 \\
\hline & Negative & 11 & 15 & 7 & 3 & & & 36 \\
\hline & Total & 11 & 15 & 9 & 5 & & & 40 \\
\hline & & Normal & $\begin{array}{l}\text { Mucus } \\
\text { activity }\end{array}$ & Erosion & Hyperemia & $\begin{array}{c}\text { Neutrophilic } \\
\text { Exudate }\end{array}$ & Phlegm & \\
\hline \multirow{4}{*}{$\begin{array}{l}\text { Glandular } \\
\text { portion } \\
(\text { Anthrum })^{2}\end{array}$} & Positive & 6 & 3 & 0 & 0 & 0 & 1 & 10 \\
\hline & Negative & 20 & 4 & 0 & 0 & 0 & 6 & 30 \\
\hline & Total & 26 & 7 & 0 & 0 & 0 & 7 & 40 \\
\hline & & Normal & $\begin{array}{l}\text { Mucus } \\
\text { activity }\end{array}$ & Erosion & Hyperemia & $\begin{array}{c}\text { Neutrophilic } \\
\text { exudate }\end{array}$ & Phlegm & \\
\hline \multirow{4}{*}{$\begin{array}{l}\text { Glandular } \\
\text { portion } \\
\text { (Fundus) }^{3}\end{array}$} & Positive & 3 & 8 & 5 & 1 & 4 & 2 & 23 \\
\hline & Negative & 6 & 0 & 1 & 0 & 1 & 9 & 17 \\
\hline & Total & 9 & 8 & 6 & 1 & 5 & 11 & 40 \\
\hline & & Normal & $\begin{array}{l}\text { Mucus } \\
\text { activity }\end{array}$ & Erosion & Hyperemia & $\begin{array}{c}\text { Neutrophilic } \\
\text { Exudate }\end{array}$ & Phlegm & \\
\hline \multirow{3}{*}{$\begin{array}{l}\text { Glandular } \\
\text { portion } \\
(\text { Body) }\end{array}$} & Positive & 1 & 0 & 1 & 0 & 0 & 1 & 3 \\
\hline & Negative & 28 & 2 & 3 & 1 & 1 & 2 & 37 \\
\hline & Total & 29 & 2 & 4 & 1 & 1 & 3 & 40 \\
\hline
\end{tabular}

${ }^{1}\left(\chi^{2}=9.38 ; \mathrm{P}=0.02\right),{ }^{3}\left(\chi^{2}=18.44 ; \mathrm{P}=0.002\right),{ }^{4}\left(\chi^{2}=5.66 ; \mathrm{P}=0.34\right)$.

the fact that infection reduces animals weight gain, causing economic losses. YAMASAKI et al. (2009) suggested that the Helicobacter might have an important role in the establishment of early lesions, increasing the possibility of them worsening with increasing age of the pigs.

The mechanisms used by the bacteria to produce various pathological conditions are not completely known (SIQUEIRA et al., 2007). The infection consequences reflect the results of the interaction between the agent and the host's immune response. Some authors stated that by understanding this relationship, it should be possible to predict, treat, and even prevent the disease (AEBISCHER et al., 2010). The inflammatory response induced by the bacteria is a key-event related to the pathogenesis (BASSO et al., 2010), as the degeneration of the surface epithelium caused by infection triggers the inflammatory response to an infiltrate, which is composed of leukocytes (neutrophils, lymphocytes, and plasma cells) (SIQUEIRA et al., 2007; BRACARENSE et al., 2013). De WITTE et al. (2017) observed that Helicobacter suis in adult pigs positively affects markers for acid secretion and inflammation, unlike the younger ones.

According to YAMASAKI et al. (2006), the association between Helicobacter spp. and the gastroesophageal ulcer occurrence in pigs has been controversial. Although, the results presented herein and by other authors (MERLINI et al., 2010; DE WITTE et al., 2017) pointed to a correlation between the presence of Helicobacter spp. and the prevalence and the severity of gastric ulcers, other studies do not (SILVEIRA et al., 2014; TAMIASSO et al., 2017).

The possible reason for this inconsistency may be the use of different techniques for determining the bacteria present, the fact that different Helicobacter spp. different strains showed higher or lower pathogenicity, and the fact that some studies were experimental while others were observational (TAYLOR \& FRIENDSHIP, 2011; DE WITTE et al., 2018). In our studies; however, IHC proved to be very sensitive to demonstrate the presence of bacteria. One of the advantages of this technique is the diagnosis of predominantly coccoid strains, which are more difficult to observe in routine stains (MCNULTY et al., 2011). 


\section{CONCLUSION}

The gastric lesions findings showed a close relationship with Helicobacter spp. in minipigs, enriching the laboratory animal pathologies list. The positive immunohistochemical findings for Helicobacter spp. in regions without ulcerative lesions suggested a saprophytic and opportunistic nature of these bacteria.

\section{BIOETHICS AND BIOSSECURITY COMMITTEE APPROVAL}

This study was approved by the UENF Animal Research Ethics Committee (CEUA), under number 373.

\section{DECLARATION OF CONFLICT OF INTERESTS}

The authors declare no conflict of interest. The founding sponsors had no role in the design of the study; in the collection, analyses, or interpretation of data; in the writing of the manuscript, and in the decision to publish the results.

\section{AUTHORS' CONTRIBUTIONS}

The authors contributed equally to the manuscript.

\section{REFERENCES}

AEBISCHER, T. et al. Inflammation, immunity and vaccines for Helicobacter. Helicobacter. v.15, S1, p.21-28, 2010. Available from: $<$ https://onlinelibrary.wiley.com/doi/full/10.1 111/j.1523-5378.2010.00777.x>. Accessed: Apr. 8, 2020. doi: 10.1111/j.1523-5378.2010.00777.x.

BANG, B. et al. Efficacy of a novel endoscopically deliverable muco-adhesive hemostatic powder in an acute gastric bleeding porcine model. PLOS ONE. v.14, n.6, p.1-9, 2019. Available from: <https://www.ncbi.nlm.nih.gov/pmc/articles/PMC6559629/ pdf/pone.0216829.pdf>. Accessed: Jul. 25, 2020. doi: 10.1371/ journal.pone. 0216829 .

BASSO, D. et al. Pathogenesis of Helicobacter pylori infection. Helicobacter. v.15, S1, p.14- 20, 2010. Available from: $\quad<$ https://onlinelibrary.wiley.com/doi/epdf/10.1111 /j.1523-5378.2010.00781.x>. Accessed: Apr. 8, 2020. doi: 10.1111/j.1523-5378.2010.00781.x.

BRACARENSE, A. P. F. R. L. et al. Helicobacter spp. infection induces changes in epithelial proliferation and E-cadherin expression in the gastric mucosa of pigs. Journal of Comparative Pathology. v.149, n.4, p.402-409, 2013. Available from: $\quad<$ https://www.sciencedirect.com/science/article/abs/pii/ S0021997513001047.https://doi.org/10.1016/j.jcpa.2013.06.002>. Accessed: Apr. 08, 2020.

DE BRUYNE, E. et al. An experimental Helicobacter suis infection causes gastritis and reduced daily weight gain in pigs. Veterinary Microbiology, v.160, n.3-4, p.449-454, 2012.
Available from: <https://www.sciencedirect.com/science/article/ pii/S0378113512003835>. Accessed: Apr. 8, 2020. doi: 10.1016/j. vetmic.2012.06.031.

DE BRUYNE, E. et al. Oral glutathione supplementation drastically reduces Helicobacter induced gastric pathologies. Scientific Reports, v.6, n.20169, 13p. 2016. Available from: $<$ https://www.nature.com/articles/srep20169.pdf $>$. Accessed: Apr. 8, 2020. doi: $10.1038 /$ srep20169.

DE WITTE, C. et al. Characterization of the nonglandular gastric region microbiota in Helicobacter suisinfected versus non-infected pigs identifies a potential role for Fusobacterium gastrosuis in gastric ulceration. Veterinary Research, v.50, n.39, p.1-18, 2019. Available from: <https:// veterinaryresearch.biomedcentral.com/track/pdf/10.1186/s13567019-0656-9>. Accessed: Apr. 8, 2020. doi: 10.1186/s13567-0190656-9.

DE WITTE, C. et al. Helicobacter suis induces changes in gastric inflammation and acid secretion markers in pigs of different ages. Veterinary Research. v.48, n.34, p.1-13, 2017. Available from: $<$ https://veterinaryresearch.biomedcentral.com/track/pdf/10.1186/ s13567-017-0441-6>. Accessed: Apr. 8, 2020. doi: 10.1186/ s13567-017-0441-6.

DE WITTE, C. et al. The role of infectious agents in the development of porcine gastric ulceration. The Veterinary Journal. v.236, n.6, p.56-61, 2018. Available from: <https://www.sciencedirect. com/science/article/abs/pii/S1090023318301333?via\%3Dihub >. Accessed: Apr. 8, 2020. doi: 10.1016/j.tvj1.2018.04.015.

FRIEDRICH, H. A. et al. Comparison of H. Pylori diagnostic tests in patients with gastric mucosa lesion. Revista da Associação Médica do Rio Grande do Sul. v.63, n.3, p.349-352, 2019. Available from: $<$ https://www.amrigs.org.br/assets/images/upload/ pdf/jornal/1580235712.pdf\#page=112>. Accessed: Jun. 09, 2020.

GIANOTTI, G. C. et al. Swine as an experimental model in biomedical research: normal physiological values. Acta Scientiae Veterinariae. v.38, n.2, p.133-137, 2010. Available from: <file://C:/Users/renat/Downloads/000767713.pdf>. Accessed: Apr. 8, 2020. doi: 10.22456 / 1679-9216.16610.

GOTTARDO, F. et al. Prevalence and risk factors for gastric ulceration in pigs slaughtered at $170 \mathrm{~kg}$. Animal. v.11, n.11, p.2010-2018, 2017. Available from: <https://www.cambridge.org/ core/journals/animal/article/prevalence-and-risk-factors-for-gas triculcerationinpigsslaughteredat $170 \mathrm{~kg} / 3 \mathrm{C} 8 \mathrm{EA} 290 \mathrm{~A} 98143616$ A8AA69D075AA5DC $>$. Accessed: Apr. 08, 2020. doi: 10.1017/ S1751731117000799.

HAESEBROUCK, F. et al. Gastric Helicobacters in domestic animals and nonhuman primates and their significance for human health. Clinical Microbiology Reviews. v.22, n.2, p.202-223, 2009. Available from: <https://www.ncbi.nlm.nih.gov/pmc/ articles/PMC2668234/pdf/0041-08.pdf > . Accessed: Apr. 8, 2020. doi: 10.1128/CMR.00041-08.

HRISTOVA, I. M. et al. Zoonotic potential of Helicobacter spp. Journal of Microbiology, Immunology and Infection. v.50, n.3, p.265-269, 2017. Available from: <https://reader.elsevier.com/ reader/sd/pii/S1684118217300555?token $=5 \mathrm{E} 370870 \mathrm{~F} 952 \mathrm{BF} 7577$ 6A62F6D1F75313A12529507D2DEAB35E6985CF9F8CD9AC2 7CF42F453A82B8CCD3320B48E98AB18>. Accessed: Apr. 08, 2020. doi: $10.1016 /$ j.jmii.2016.11.003. 
JOOSTEN, M. et al. Case report: Helicobacter suis infection in a pig Veterinarian. Helicobacter. v.18, n.5, p.392-396, 2013. Available from: $<$ https://onlinelibrary.wiley.com/doi/epdf/10.1111/ hel.12054>. Accessed: Apr. 8, 2020. doi: 10.1111/hel.12054.

KOGA, T. et al. Contribution of ferrous iron to maintenance of the gastric colonization of Helicobacter pylori in miniature pigs. Microbiological Research. v.157, n.4, p.323-330, 2002. Available from: <https://www.sciencedirect.com/science/ article/pii/S0944501304700932>. Accessed: Apr. 8, 2020. doi: 10.1078/0944-5013-00169.

KUMAR, S. et al. An experimental Helicobacter suis infection reduces daily weight gain in pigs. In: Proceedings of the 21th IPVS Congress. Vancouver, Canada. p.80, 2010.

LIANG, J. et al. Multilocus sequence typing of the porcine and human gastric pathogen Helicobacter suis. Journal of Clinical Microbiology. v.51, n.3, p.920-926, 2013. Available from: $<$ https://jcm.asm.org/content/51/3/920>. Accessed: Apr. 8, 2020 doi: 10.1128/JCM.02399-12.

LOUGHLIN, V. H. M. et al. Helicobacter spp. in the stomach of pigs in the Río Cuarto area, Córdoba, Argentina. Academia Journal of Biotechnology, vol.7, n.1, p.8-13, 2019. Available from: <https:// academiapublishing.org/journals/ajb/pdf/2019/Jan/Loughlin\%20 et $\% 20$ al.pdf $>$. Accessed: Apr. 8, 2020. doi: 10.15413/ajb.2018.0123.

MAEDA, H. et al. High-adhesion gelatin films reduce inflammation and tissue contraction during gastric ulcer healing following endoscopic submucosal dissection: a miniature swine model. Gastrointestinal Endoscopy. v.89, n.6, p.1, 2019. Available from: <https://www.giejournal.org/article/S0016-5107(19)313057/pdf $>$. Accessed: Jul. 25, 2020. doi: 10.1016/j.gie.2019.03.1114.

MARIANO, M. Minisuíno (minipig) na pesquisa biomédica experimental. O Minipig BR 1. Acta Cirúrgica Brasileira. v.18, n.5, p.387-391, 2003. Available from: <https://www.scielo.br/pdf/ acb/v18n5/17432.pdf $>$. Accessed: Apr. 8, 2020. doi: 10.1590/ S0102-86502003000500003.

MCNICHOLL, A. G. et al. Accuracy of the ultra-rapid urease test for diagnosis of Helicobacter pylori infection. Gastroenterología y Hepatología. v.40, n.10, p.651-657, 2017. Available from: <https:// www.elsevier.es/es-revista-gastroenterologia-hepatologia-14-articuloaccuracy-ultra-rapid-urease-test-for-S0210570517301851> Accessed: Jun. 9, 2020. doi: 10.1016 / j.gastrohep.2017.07.007.

MCINTOSH, K. A. et al. In situ detection of urease-positive Helicobacter pylori-like organisms on swine gastric mucosa. The Canadian Journal of Veterinary Research. v.74, n.3, p.237240, 2010. Available from: <http://www.ncbi.nlm.nih.gov/pmc/ articles/PMC2896808/>. Accessed: Apr. 8, 2020. PMC2896808.

MCNULTY, C. A. M. et al. Diagnosis of Helicobacter pylori infection. Helicobacter. v.16, sup.1, p.10-18, 2011 Available from: <https://onlinelibrary.wiley.com/doi/epdf/10.1 111/j.1523-5378.2011.00875.x>. Accessed: Apr. 23, 2020. doi: $10.1111 / j .1523-5378.2011 .00875 . x$

MERLINI, L.S. et al. Lesões gástricas em suínos e a relação com a presença de Helicobacter spp. V Fórum Internacional de Suinocultura. Curitiba-PR. Anais. p.706-707, 2010.

NAKAGAWA, S. et al. The Resolution of Helicobacter suisassociated gastric lesions after eradication therapy. Internal
Medicine. v.57, n.2, p.203-207, 2018. Available from: <https:// www.jstage.jst.go.jp/article/internalmedicine/57/2/57_8971-17/ pdf/-char/en>. Accessed: Apr. 8, 2020. doi: 10.2169/ internalmedicine.8971-17.

OKUBO, B. M. et al. Prevalência de Helicobacter spp. em cães de Campo Grande-MS. Ciência Animal Brasileira. v.18, n.1, p.1-10, 2017. Available from: <https://www.scielo.br/scielo. php? script $=$ sci arttext\&pid $=$ S1809-68912017000100304 $>$. Accessed: Jun. 9, 2020. doi: 10.1590/1089-6891v18e-17286.

PADRA, M. et al. Helicobacter suis binding to carbohydrates on human and porcine gastric mucins and glycolipids occurs via two modes. Virulence. v.9, n.1, p.898-918, 2018. Available from: <https://www.tandfonline.com/doi/full/10.10 80/21505594.2018.1460979>. Accessed: Apr. 23, 2020. doi: $10.1080 / 21505594.2018 .1460979$

POUTAHIDIS, T. et al. Helicobacter pylori-induced gastritis in experimentally infected conventional piglets. Veterinary Pathology. v.38, n.6. p.667-678, 2001. Available from: <https:// journals.sagepub.com/doi/pdf/10.1354/vp.38-6-667>. Accessed: Apr. 8, 2020. doi: 10.1354/vp.38-6-667.

RIMBARA, E. et al. Complete genome sequence of Helicobacter suis strain SNTW101c, originally isolated from a patient with nodular gastritis. Microbiology Resource Announcements. v.9, n.1, p.1-3, 2020. Available from: <https://mra.asm.org/content/ ga/9/1/e01340-19.full.pdf $>$. Accessed: Jul. 25, 2020.

RODRIGUEZ, B. J. et al. Determinación de Helicobacter spp. en cerdos en el departamento de Antioquia, Colombia. Revista Colombiana de Ciências Pecuárias. v.21, n.2, p.210-218, 2008. Available from: <www.scielo.org.co/pdf/rccp/v21n2/v21n2a03. pdf $>$. Accessed: Jun. 9, 2020.

SILVEIRA, R. L. et al. Gastroesophageal pre-ulcerative lesions in minipigs. Revista Brasileira de Ciência Veterinária. v.22, n.3-4, p.160-164, 2015. Available from: <https://periodicos.uff. br/rbcv/article/view/7679/5962>. Accessed: Jun. 8, 2020. doi: 10.1590/1678-7251

SILVEIRA, R. L. et al. Helicobacteriose em leitões: Imunohistoquímica em amostras colhidas por meio de gastroscopia. Arquivo Brasileiro de Medicina Veterinária e Zootecnia. v.66, n.6, p.1681-1686, 2014. Available from: <https://www. scielo.br/pdf/abmvz/v66n6/0102-0935-abmvz-66-06-01681.pdf $>$. Accessed: Apr. 8, 2020. doi: 10.1590/1678-7251.

SIQUEIRA, J. S. et al. Aspectos gerais nas infecções por Helicobacter pylori: Revisão. Revista Brasileira de Análises Clínicas. v.39, n.1, p.9-13, 2007. Available from: $<$ https://www.researchgate.net/publication/280002792 Aspectos_Gerais_nas_Infeccoes_por_Helicobacter_pylori Revisao\#: :text=RESUMO $\% 20 \% 2 \mathrm{D} \% 20 \mathrm{O} \% 20$ Helicobacter $\% 20$ pylori\%20\%C3\%A9,g\%C3\%A 1 strico\%20 \% $\% 20$ a \% 20 \%C3\%BAlcera\%20p\%C3\%A9ptica>. Accessed: Apr. 8, 2020.

SWINDLE, M. M.; SMITH, A. C. Swine in the laboratory: Surgery, anesthesia, imaging and experimental techniques. Boca Raton: CRC Press, 2016. 593p.

SZEREDI, L. et al. Study on the role of gastric Helicobacter infection on gross pathological and histological lesions of the stomach in finishing pigs. Acta Veterinariae Hungarica. v.53, n.3, p.371-383, 2005. Available from: <https://www.researchgate. 
net/publication/7606950_Study_on_the_role_of_gastric Helicobacter infection in gross pathological and histological lesions_of_the_stomach_in_finishing_pigs $>$. Accessed: Apr. 8, 2020. doi: $10.1556 /$ AVet.53.2005.3.10.

TAMIASSO, N. V. et al. Ausência de Helicobacter spp. em lesões gástricas de suínos pelo método Warthin-Starry. Veterinária e Zootecnia. v.24, n.2, p.336-344, 2017. Available from: $<$ https://rvz. emnuvens.com.br/rvz/article/view/315/175>. Accessed: Apr. 8, 2020.

TAYLOR, S.; FRIENDSHIP, R. M. A systematic review of the association between Helicobacter spp. and the development of gastric ulcers in swine. In: Proceedings of $\mathbf{1 1}^{\text {th }}$ Annual Meeting of American Association of Swine Veterinarians. Phoenix, Arizona-USA. p.337-338, 2011.

THOMSON, J. R.; FRIENDSHIP, R. M. Digestive system. In: ZIMMERMAN, J.J. et al. Diseases of swine. Hoboken: Wiley Blackwell. 2019. Cap.15, p.234-263.
VARGAS, L. J. et al. Diagnostic methods for detecting H.pylori infection: systematic review. Pará Research Medical Journal. v.3, n.2, p.1-6, 2019. Available from: <https://www.prmjournal. org/article/10.4322/prmj.2019.009/pdf/prmjournal-3-2-e09.pdf $>$. Accessed: Jun. 9, 2020. doi: 10.4322/prmj.2019.009.

YAMASAKI, L. et al. Lesões gástricas em suínos: Ocorrência e relação com o gênero, peso ao abate e presença de Helicobacter sp. Semina Ciências Agrárias. v.27, n.3, p.463-470, 2006. Available from: <file://C:/Users/renat/Downloads/Lesoes gastricas_em_suinos_Ocorrencia_e_relacao_co.pdf $>$. Accessed: Apr. 8, 2020. doi: $10.5433 / 1679-035 \overline{5} 9.2006 \bar{v} 27 \mathrm{n} 3 \mathrm{p} 463$.

YAMASAKI, L. et al. Alterações histológicas da pars esophagea de suínos e sua relação com Helicobacter spp. Arquivo Brasileiro de Medicina Veterinária e Zootecnia. v.61, n.3, p.553-560, 2009. Available from: <https://www.scielo.br/ pdf/abmvz/v61n3/05.pdf>. Accessed: Apr. 8, 2020. doi: 10.1590/ S0102-09352009000300005. 